\title{
Simple and Reliable DNA Extraction Method for the Dark Pigmented Fungus, Cercospora sojina
}

\author{
Ji-Seong Kim, Sang-Gyu Seo, Byung-Ki Jun, Jin-Won Kim and Sun-Hyung Kim* \\ Department of Environmental Horticulture, The University of Seoul, Seoul 130-734, Korea \\ (Received on July 18, 2010; Accepted on August 8, 2010)
}

\begin{abstract}
This study used a modified cetyltrimethylammonium bromide (CTAB) method to efficiently extract DNA from the plant pathogenic fungus Cercospora sojina. Total DNA yield obtained by this method was approximately $1 \mathrm{mg} / \mathrm{g}$ of mycelia (fresh weight), and the mean ratio of A260/A280 and A260/A230 were 2.04 and 2.1, respectively. The results of random amplified polymorphic DNA (RAPD) analysis, digestion with restriction enzymes, and Southern hybridization indicated that polysaccharides were effectively removed by this method, and the resulting DNA was sufficient for use in subsequent molecular analysis.
\end{abstract}

Keywords : Cercospora sojina, DNA extraction, fungus, RAPD, Restriction enzyme

The molecular analyses of fungal DNA proved to be a challenge because of problems caused by the abundance of inhibitors, such as polysaccharides and phenolic compounds, which are difficult to eliminate and inhibit the action of enzymes (Sreenivasaprasad, 1999). Cercospora sojina, which belongs to the family Mycosphaerellaceae, is a causal agent of frogeye leaf spot in soybean (Hartman et al., 1999; Goodwin et al., 2001).

Numerous existing reports have described procedures for the extraction and purification of fungal DNA (Möller et al., 1992; Löeffler et al., 1997; Sreenivasaprasad, 1999; Kuhad et al., 2004; Mahuku, 2004; Karakousis et al., 2006). Although several methods for the isolation of DNA from C. sojina already exist, most methods yield a low quantity of DNA, which is usable only for polymerase chain reaction (PCR) analysis and not for Southern hybridization.

In many studies, a lysis buffer containing cetyltrimethylammonium bromide (CTAB) was used to extract fungal DNA by using the plant genomic DNA extraction method (Möller et al., 1992; Sreenivasaprasad, 1999; Kuhad et al., 2004). However, this procedure was complicated and timeconsuming because of its numerous extraction steps for

\footnotetext{
*Corresponding author.

Phone) +82-02-2210-5728, FAX) +82-02-2210-2838

E-mail)mongdal@uos.ac.kr
}

polysaccharide elimination, cell lysis, and extract transfer. The DNA extraction method described in this study is particularly suitable for the extraction of DNA from $C$. sojina. The frozen material that is ground using an AutoMill TK AM4 (Tokken Inc.) can be used immediately for DNA isolation. We followed the protocols (Table 1) and achieved a total DNA yield of $984.8 \pm 21.6 \mu \mathrm{g} / \mathrm{g}$ of C. sojina mycelia (fresh weight). The absorbance ratio of A260 nm/ A280 nm ranged from 2.031 to 2.049 , and the A260 nm/ A230 nm ratio ranged from 2.076 to 2.198 , thereby indicating the absence of major contaminants like proteins and polysaccharides (Table 2). We electrophoresed the DNA extracted from C. sojina on $1 \%$ agarose gels and obtained DNA with high molecular weight (Fig. 1A).

The cell wall of many pathogenic fungi is resistant to enzymatic cell wall disruption (Löeffler et al., 1997). Proteinase $\mathrm{K}$ or lyticase treatment alone was less efficient than grinding for cell wall degradation (Karakousis et al., 2006). In a previous study, proteinase $\mathrm{K}$ was added to inactivate proteins, and it disrupted the cell wall after grinding (Mahuku, 2004). However, proteinase $\mathrm{K}$ may act as a strong enzyme inhibitor. Unlike in other procedures, in our proposed method, fungal materials were frozen in liquid $\mathrm{N}_{2}$ prior to extraction and was then ground using the Auto-Mill, thereby eliminating the need for lyophilization.

Phenolics and polysaccharides that contaminate DNA are responsible for incomplete PCR amplification and inhibit the action of restriction enzymes (Sreenivasaprasad, 1999). Acidic polysaccharides, in particular, inhibit random amplified polymorphic DNA (RAPD) analysis (Pandey et al., 1996). Polysaccharides account for about $80-90 \%$ of the dry matter in fungal cell wall (Farkas 1979), and some fungi produce high levels of polysaccharides in culture (Möller et al., 1992). In sweet potato, DNA extraction using CTAB has been known to eliminate polysaccharides (Kim and Hamada, 2005). Removal of the acidic polysaccharides by using CTAB may result in the formation of a strong complex with high molar mass in the presence of $1.4 \mathrm{M}$ sodium chloride (Kuhad et al., 2004). To evaluate the suitability of the isolated DNA for RAPD procedures, we subjected the entire DNA to RAPD analysis. Because PCR amplification is highly sensitive to impurities, it is highly 
Table 1. DNA extraction procedure and the approximated time required for each step

\begin{tabular}{|c|c|c|}
\hline & Procedure & Time \\
\hline 1 & $\begin{array}{l}\text { Culturing Cercospora sojina and harvesting } \\
\text { Cercospora sojina was incubated on } 10 \%(\mathrm{v} / \mathrm{v}) \mathrm{V} 8 \text { juice agar }\left(100 \mathrm{ml} \text { of } \mathrm{V} 8 \text { juice, } 1 \mathrm{~g} \text { of } \mathrm{CaCO}_{3} \text {, and } 15 \mathrm{~g} \text { of agar }\right. \\
\left.\text { in } 1 \text { liter } \mathrm{dH}_{2} \mathrm{O}\right) \text { for } 10 \text { days at } 25^{\circ} \mathrm{C} \text {. Agar blocks with mycelia from the edge of the colony were soaked in } 10 \% \mathrm{~V} 8 \\
\text { juice liquid media and voltexed vigorously for } 1 \text { minute. Mycelia suspension was incubated with shaking at } 140 \\
\text { rpm for } 5 \text { days. Cultures were harvested by filtration through filter paper, washed five times with } \mathrm{dH}_{2} \mathrm{O} \text {, squeezed } \\
\text { gently, and stored at }-80^{\circ} \mathrm{C} \text {. }\end{array}$ & 5 days \\
\hline 2 & $\begin{array}{l}\text { Pulverization of fungal mycelia } \\
\text { Mycelia were grinded under liquid } \mathrm{N}_{2} \text { using Auto-Mill and transferred to tube. }\end{array}$ & $2-3 \mathrm{~min}$ \\
\hline 3 & $\begin{array}{l}\text { Cell lysis }^{\mathrm{a}} \\
\text { Four-fold volumes of } 2 \mathrm{X} \text { CTAB buffer }(1 \% \mathrm{CTAB}, 100 \mathrm{mM} \text { Tris-HCl pH 9.5, } 20 \mathrm{mM} \text { EDTA pH 8.0, } 1.4 \mathrm{M} \mathrm{NaCl} \\
\text { and } 1 \% \text { mercaptoethanol) and two-fold volumes of chloroform/isoamyl alcohol }(24: 1, \mathrm{v} / \mathrm{v}) \text { were added. } \\
\text { The mixture was agitated for } 30 \mathrm{~min} \text { at } 65 \text { with occasional deflation. }\end{array}$ & $30 \mathrm{~min}$ \\
\hline
\end{tabular}

\section{Cell debris and contaminants precipitation}

Two-fold volume of chloroform/isoamyl alcohol was added, gently mixed, and centrifuged at $13000 \mathrm{rpm}$ for 10

$4 \min$ at $4^{\circ} \mathrm{C}$.

If the supernatant was not clear, we recommend more chloroform/isoamyl alcohol to be added for higher purity of

$15 \min$ DNA.

\section{DNA precipitation}

5 Clear supernatant was transferred to a new tube and an equal volume of 2-propanol was added. The mixture was gently mixed and allowed to precipitate at room temperature

\footnotetext{
Preparation of DNA solution

6 After the supernatant were discarded, $70 \%$ ethanol was added to the DNA pellet and centrifuged at $1300 \mathrm{rpm}$ for 15 min at $4^{\circ} \mathrm{C} .70 \%$ ethanol was discarded and pellet was dried on silica gel. Then, the DNA pellet was re-suspended in distilled water or $1 \mathrm{X}$ TE containing $40 \mu \mathrm{g} / \mathrm{ml}$ RNase with no agitation.

${ }^{a}$ Möller et al. (1992), Sreenivasaprasad (1999) and Kuhad et al. (2004) used CTAB method to extract fungal DNA. Möller's method contains additional CTAB step to eliminate polysaccharide and use proteinase K. Sreenivasaprasad's protocol includes several cycle of phenol-chloroform precipitation. Kuhad's method also contains additional CTAB step for elimination of polysaccharide. These methods are time consuming and complicated. In this method, cell lysis and elimination of polysaccharide were conducted in one step and mercaptoethanol was used to prevent DNA degradation.
}

Table 2. Purity and yield of total DNA measured by spectrophotometrically

\begin{tabular}{cccc}
\hline \hline \multirow{2}{*}{ Isolate No. } & \multicolumn{2}{c}{ Absorbance Ratio } & Yield $(\mu \mathrm{g} / \mathrm{g})$ \\
\cline { 2 - 4 } & OD 260/280 & OD 260/230 & Fresh weight \\
\hline 1 & 2.031 & 2.076 & 964 \\
2 & 2.045 & 2.198 & 999 \\
3 & 2.038 & 2.080 & 1,010 \\
4 & 2.031 & 2.076 & 990 \\
5 & 2.049 & 2.087 & 961 \\
\hline
\end{tabular}

important to produce clean DNA for the successful amplification of fungal DNA. We used the CTAB method to amplify genomic DNA from $5 C$. sojina isolates, and the DNA produced distinct bands (Fig. 1B), indicating the absence of polysaccharides. Polysaccharides also inhibit the activity of restriction enzymes (Sreenivasaprasad, 1999). When the DNA was digested with Hind III and XbaI, it was completely digested (Fig. 1C) and was usable for Southern hybridization. Southern hybridization with a digoxigenin
(DIG)-labeled probe produced distinct bands (Fig. 1D). These results demonstrate that the purity and quality of fugal genomic DNA was high enough for restriction enzyme digestion.

Phenol-chloroform extraction is commonly used to remove proteins from fungal genomic DNA (Sreenivasaprasad, 1999; Kuhad et al., 2004; Karakousis et al., 2006). Phenol and chloroform are organic solvents that cause protein precipitation after denaturation (Asakura et al., 1978). While chloroform is only slightly soluble in water, phenol is more soluble in water; therefore, the extracted DNA may be contaminated by phenol. In our proposed protocol, chloroform/isoamyl alcohol without phenol had no detrimental effect and was thus suitable for the extraction of fungal genomic DNA of high quality. The extraction step was simplified by using only chloroform/isoamyl alcohol (24:1, $\mathrm{v} / \mathrm{v}$ ) and eliminating phenol. Hence, the frequency of centrifugation was reduced.

Polysaccharides are known to precipitate in 2-propanol and ethanol (Manna et al., 1996). Moreover, it has been observed that most of the DNA immediately forms thread- 
Table 3. Absorbance ratio and yield of total DNA from five isolates under room temperature (RT) or $-20^{\circ} \mathrm{C}$ incubation for 30 minutes in the procedure of isopropanol precipitation

\begin{tabular}{cccr}
\hline \hline & \multicolumn{2}{c}{ Absorbance Ratio } & \multicolumn{1}{c}{$\begin{array}{c}\text { Yield }(\mu \mathrm{g} / \mathrm{g}) \\
\text { Fresh weight }\end{array}$} \\
\cline { 2 - 3 } & OD 260/280 & OD 260/230 & \\
\hline RT & $2.039 \pm 0.008^{\mathrm{a}}$ & $2.103 \pm 0.053$ & $984.8 \pm 21.6$ \\
$-20^{\circ} \mathrm{C}$ & $2.000 \pm 0.009$ & $1.945 \pm 0.020$ & $1031.6 \pm 67.7$ \\
\hline
\end{tabular}

${ }^{a}$ Values are mean $\pm \operatorname{SD}(n=5)$

\section{A}

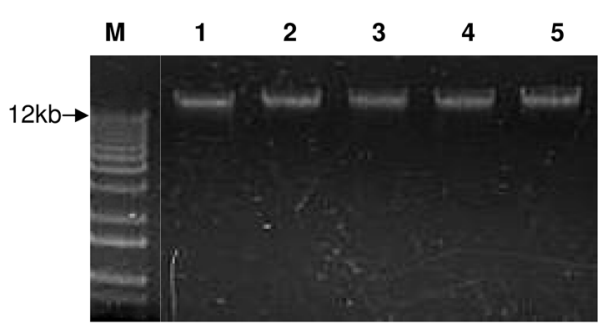

like structures and can be separated using low-speed centrifugation at room temperature. Prolonged precipitation of DNA in isopropanol either at -20 or at $-80^{\circ} \mathrm{C}$ caused contamination of the DNA with pigments and polysaccharides. CTAB and isopropanol possibly form a strong structure with high molar mass acidic polysaccharides (Kuhad et al., 2004). The quality of DNA we obtained after incubation at room temperature was higher than that obtained after

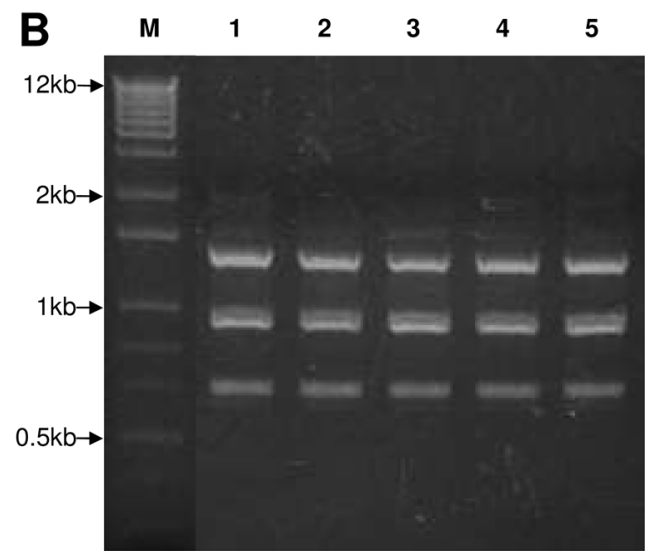

Fig. 1. Agarose gel electrophosis of genomic DNA and PCR amplication from five $C$. sojina isolates. A. $2 \mu$ g of total DNA were loaded on $1 \%$ agarose gel. B. PCR products amplified using arbitrary decamer primer were loaded. Polymerase chain reaction (PCR) was performed in a total volume of $20 \mu \mathrm{l}$ containing $30 \mathrm{ng}$ of DNA and 5 pmole of arbitrary decamer primer (5'-ATCTGCGAGC-3') using PCR PreMix (Bioneer). PCR conditions were as follows: $94^{\circ} \mathrm{C}$ for 3 minutes, 45 cycles of $94^{\circ} \mathrm{C}$ for 1 minute, $36^{\circ} \mathrm{C}$ for 1 minute, $72^{\circ} \mathrm{C}$ for 2 minutes, and $72^{\circ} \mathrm{C}$ for 5 minutes for final extension. PCR products were electrophoresed in a $1.5 \%$ agarose gel in $0.5 \mathrm{X}$ TAE.
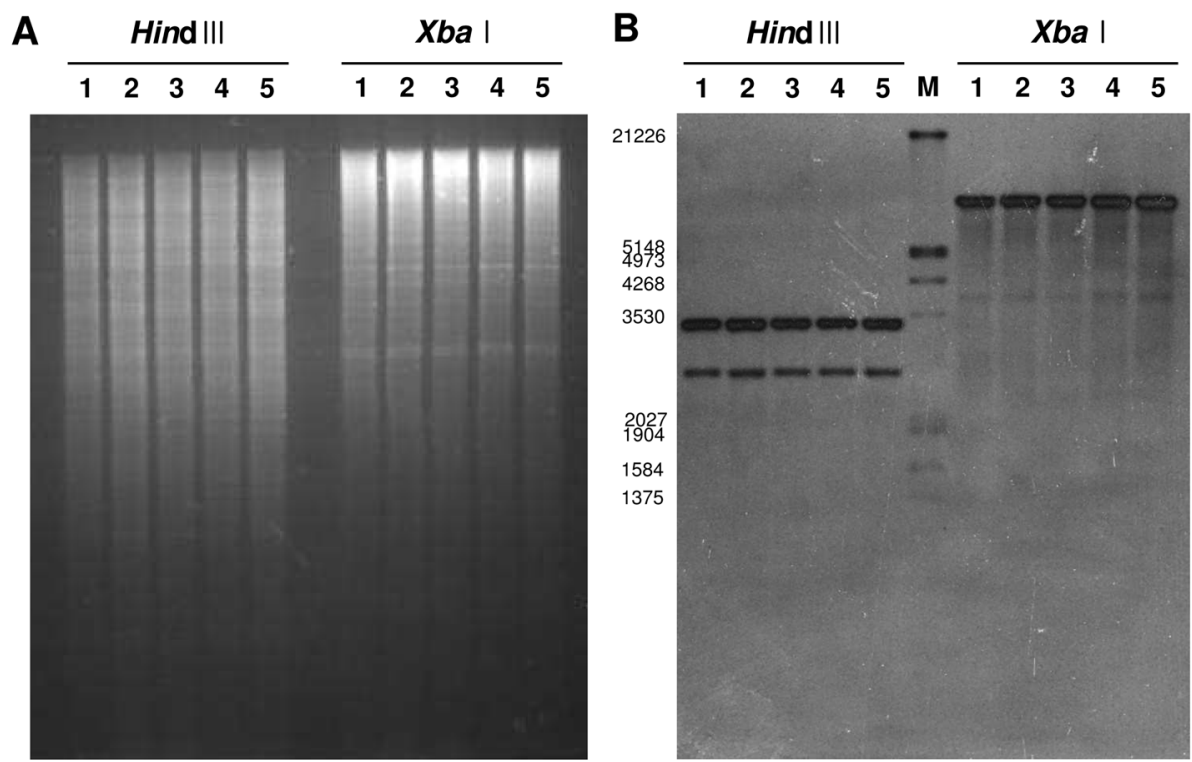

Fig. 2. Agarose gel electrophoresis of digested DNA and southern hybridization of genomic DNA. A. Genomic DNA from five Cercospora sojina isolates were digested with Hind III and XbaI. B. Hybridization analysis of the DNA from five isolates of Cercospora sojina. In the Southern hybridization, total DNA $(20 \mu \mathrm{g})$ was digested with HindIII and XbaI, fractionated via electrophoresis on $0.8 \%$ agarose gel, transferred to positively charged Nylon membranes (Roche Molecular Biochemicals), then hybridized with probe specific to common DNA fragment of five Cercospora sojina isolates obtained RAPD analysis. Pre-hybridization, hybridization, and detection were performed according to the instructions of the DIG system (Roche Molecular Biochemicals). 
isopropanol precipitation involving 30-min incubation at $-20^{\circ} \mathrm{C}$ (Table 3). Complete DNA restriction analysis showed that polysaccharides were absent in the extract (Fig. 1C).

In conclusion, we have presented a method for the rapid isolation of fungal DNA that is free of contaminants, which interfere with complete digestion by endonucleases and PCR amplification. The extraction took approximately 3-4 $\mathrm{h}$, including the time for resuspension of the dried DNA pellet. Similar protocols have been previously described for the extraction from Magnaporthe oryzae mycelia (Chi et al., 2009). However, unlike the previous protocols, the extraction step was simplified by using only chloroform/ isoamyl alcohol $(24: 1, \mathrm{v} / \mathrm{v})$, thereby eliminating phenol; the frequency of centrifugation was also reduced. This method was also applied to Alternaria sp. and Fusarium sp. and genomic DNA was successfully extracted. (data not shown)

Our procedure is ideal for the rapid isolation of fungal DNA from many different species and is time- and costeffective (up to 24 samples can be processed simultaneously).

\section{References}

Asakura, T., Adachi, K. and Schwartz, E. 1978. Stabilizing effect of various organic solvents on protein. J. Biol. Chem. 25: 6423-6425.

Chi, M. W., Park, S. Y. and Lee, Y. H. 2009. A quick and safe method for fungal DNA extraction. Plant Pathol. J. 25:108111.

Daub, M. E. and Chung, K. R. 2007. Cercosporin: a photoactivated toxin in plant disease. APSnet Feature Story. February www.apsnet.org

Farkas, V. 1979. Biosynthesis of cell walls of fungi. Microbiol. Reviews 43:117-144.

Goodwin, S. B., Dunkle, L. D. and Zismann, V. L. 2001. Phyloge- netic analysis of Cercospora and Mycosphaerella based on the internal transcribed spacer region of ribosomal DNA. Phytopathology 91:648-658.

Hartman, G. L., Sinclair, J. B. and Rupe, J. C. 1999. Frogeye leaf spot. In: Compendium of soybean diseases, 4rd edn. The American Phytopathological Society Press. St Paul. pp. 20-21.

Karakousis, A., Tan, L., Ellis, D., Alexiou, H. and Wormald, P. J. 2006. An assessment of the efficiency of fungal DNA extraction methods for maximizing the detection of medically important fungi using PCR. J. Microbiol. Methods 65:38-48.

Kim, S. H. and Hamada, T. 2005. Rapid and reliable method of extracting DNA and RNA from sweetpotato, Ipomoea batatas (L). Lam. Biotechnol. Lett. 27:1841-1845.

Kuhad, R. C., Kapoor, R. K. and Lal, R. 2004. Improving the yield and quality of DNA isolated from white-rot fungi. Folia Microbiol. 49:112-116.

Löeffler, J., Hebart, H., Shumacher, U., Reitze, H. and Einsele, H. 1997. Comparison of different methods for extraction of DNA of fungal pathogens from cultures and blood. J. Clin. Microbiol. 35: 3311-3312.

Mahuku, G S. 2004. A simple extraction method suitable for PCR based analysis of plant, fungal, and bacterial DNA. Plant Mol. Biol. Rep. 22:71-81.

Manna, B., Gambhir, A. and Ghosh, P. 1996. Production and rheological characteristics of the microbial polysaccharide gellan. Lett. Applied Microbiol. 23:141-145.

Möller, E. M., Bahnweg, G, Sandermann, H. and Geiger, H. H. 1992. A simple and efficient protocol for isolation of high molecular weight DNA from filamentous fungi, fruit bodies, and infected plant tissues. Nucleic Acids Res. 20:6115-6116.

Pandey, R. N., Adams, R. P. and Flournoy, L. E. 1996. Inhibition of random amplified polymorphic DNAs (RAPDs) by plant polysaccharides. Plant Mol. Biol. Rep. 14:17-22.

Sreenivasaprasad, S. 1999. Isolation of fungal nucleic acids. In R. Rapley (ed) The Nucleic Acid Protocols Handbook, Humana Press. Totowa. pp 37-45. 